\title{
THE US AND TURKEY IN SEARCH OF REGIONAL STRATEGY: TOWARDS ASYMPTOTIC TRAJECTORIES ${ }^{1}$
}

\author{
Kostas Ifantis ${ }^{2}$ \& Ioannis Galariotis ${ }^{3}$ \\ Kadir Has University and Athens University
}

Security relations with the US have been critical for Turkey. Cold War strategic imperatives dictated typical bandwagoning policies, although disagreements and frictions were present at times. In the $2000 \mathrm{~s}$, a combination of domestic developments and rapidly changing regional security patterns has resulted in a more assertive Turkish regional security policy, which for many represents a departure from traditional Kemalist principles. This article attempts to assess the current course of Turkish regional security engagement and the extent to which relations between the USA and Turkey are subject to major change. The analytical context accounts for the impact of domestic, regional and global levels. The empirical focus is on Turkey's involvement in the Syrian sectarian conflict and on the trajectory of the bilateral relations with Israel.

\section{Keywords: US-Turkish relations, Israel, Middle East, Eastern Mediterranean, Syria, regional security.}

Resumen:

Las relaciones de seguridad con los EEUU han resultado siempre vitales para Turquía. Los imperativos estratégicos de la Guerra Fría dictaron clásicas políticas de "bandwagoning", si bien los desacuerdos y fricciones varias estuvieron presentes en todo momento. En la década del 2000, una combinación de particulares cambios en la escena doméstica y patrones de seguridad regional en rápida mutación, dieron lugar a una política de seguridad regional turca, que para muchos representa una clara ruptura con los principios clásicos del Kemalismo. Este artículo intenta evaluar el actual curso de los compromisos en política regional de Turquía y determinar hasta qué punto las relaciones entre los EEUU y Turquía están sujetas a cambios relevantes. El contexto analítico tomará en cuenta el impacto tanto de los niveles doméstico, regional como global. Empíricamente, este artículo se fijará en la implicación de Turquía en el conflicto sectario sirio y en la trayectoria de las relaciones bilaterales con Israel.

Palabras clave: Las relaciones EEUU-Turquía, Israel, Oriente Medio, Mediterráneo Oriental, Siria, seguridad regional.

Copyright (C) UNISCI, 2014.

Las opiniones expresadas en estos artículos son propias de sus autores, y no reflejan necesariamente la opinión de UNISCI. The views expressed in these articles are those of the authors, and do not necessarily

reflect the views of UNISCI.

\footnotetext{
${ }^{1}$ A much earlier draft of this article was published as 'The US and Turkey in the fog of regional uncertainty', GreeSE Paper no 73, HO/LSE, August 2013. To Mustafa Aydin, Mitat Celikpala, Serhat Guvenc, Ahmet Han, Emre Iseri, Soli Ozel, and Dimitris Triantaphyllou we express our gratitude for taking the time to either discuss some of the issues that are raised in this article or read earlier drafts and provide most valuable comments. Equally grateful we are towards the reviewers of UNISCI. Of course, the usual but absolutely valid disclaimer applies.

${ }^{2}$ Kostas Ifantis is currently a Visiting Professor at Kadir Has University in Istanbul. He is, also, an Associate Professor of International Relations in the Department of Political Science and Public Administration, University of Athens. He worked as a Lecturer in International and European Politics at the Universities of Bradford and Portsmouth, UK (1991-1995). He was USIS Visiting Fellow at the Center for Political studies, University of Michigan, Ann Arbor (1998), Fulbright Visiting Scholar at the John F. Kennedy School of Government, Harvard University (2002) and IAA Senior Research Fellow at the Hellenic Observatory of the LSE (2009).

Correspondence: kifantis@pspa.uoa.gr and konstantinos.ifantis@khas.edu.tr.

${ }^{3}$ Ioannis Galariotis is post-doctoral research fellow at the Athens University of Economics and Business. He holds a Ph.D. in political science and international relations from the National and Kapodistrian University of Athens, Department of Political Science and Public Administration. He also holds a B.Sc. in Economics (University of Athens) and postgraduate degrees in International Political Economy (Newcastle University), European Integration (Essex University) and Economics (Tilburg University). His research interests focus on international organizations, foreign policy analysis, international relations theory and international political economy.
} 


\section{Hintir dyduction}

The fall of the Berlin Wall changed fundamentally the way the US-Turkish relations have defined over the years after the end of the Second World War. Overarching Cold War pressures that were responsible for the determination of US-Turkish relations have completely disappeared or dramatically been altered. As a result, regarding US foreign policy, Turkey is no longer a Cold War outpost that should be held protected at all cost. Their relations have changed over the years subject to the emergence of new power centers in the world, regional upheavals and remarkable domestic transformations in Turkey. Both have become more realistic and careful regarding the strengths and limits of their relationship and they have adopted a more straightforward approach in the demands they make upon each other. ${ }^{4}$

The notable transformations inside Turkey's political scene seem to be affecting foreign policy imperatives both in the US and Turkey alike. The Kemalist secular tradition has been challenged as the dominant identity font and the ruling Justice and Development Party (AKP) has been successful in the struggle for power against the old secularist guard. Based on the "Davutoglu's doctrine", Turkish foreign policy self-determination and activism has become more pronounced $^{5}$ and Turkey has espoused a much more Ankara-centric approach to the Middle East and Eastern Mediterranean. Washington, at the same time, has defined as the epicenter of its foreign policy aims the strategic relations with East Asia focusing less on a more direct involvement in the Middle East. Both though look like to be ill equipped for the changes unfolding in the region since 2011.

This article argues that the diversity of actors, roles and alleged interests has resulted in security anxiety and policies often without basic direction, coherence and well-assessed goals and against a background of a daily changing regional setting. One fundamental question albeit hard to answer at this juncture - is whether Turkey under AKP would increasingly find itself at odds with the West should it continue to pursue what some have described as a "neoOttoman" course. ${ }^{6}$

The following analysis attempts to evaluate the course of security relations between the USA and Turkey against an exceedingly turbulent Eastern Mediterranean and Middle Eastern subsystem. Firstly, the article will discuss the current US foreign policy priorities and preferences under the Obama Administration, focusing mainly on the Eastern Mediterranean/Middle Eastern strategic complex. Secondly, it will examine Turkey's changing regional security setting and the domestic pressures, which are present at the effort of the AKP government to revise its regional stance in a rather radical way. Particular attention is given to the deterioration of the relations between Turkey and Israel, Turkish policy in Syria and the extent to which they do influence regional security dynamics and dilemmas.

\footnotetext{
${ }^{4}$ Larrabee, Stephen (2010): Troubled Partnership: US-Turkish Relations in an Era of Global Geopolitical Change, RAND Corporation, Santa Monica.

${ }^{5}$ See Falk, Richard: "Can the U.S. Government Accept an Independent Turkish Foreign Policy in the Middle East?", Turkish Inside, vol.16, no.1 (Winter 2014), pp.7-18.

${ }^{6}$ Many believe that the AKP leadership seeks to reverse the secular legacy of Mustafa Kemal by eliminating restrictions on Islam and undercutting "the old judicial and military order that guarded against the Islamization of Turkey". See Fradkin, Hillel and Libby, Lewis: "Erdogan’s Grand Vision: Rise and Decline", World Affairs Journal, (March/April 2013), at http://www.worldaffairsjournal.org/print/63552.
} 


\section{Washington's Far Eastern Strategic Gaze}

In 2008, The Economist shared the view that the Bush foreign policy doctrine will not last in its present form, but nor will it disappear altogether. ${ }^{7}$ Almost six years later, President Obama has succeeded in generating some change despite domestic challenges and limited resources. A much stronger focus on strengthening international institutions and galvanizing collective action $^{8}$ has meant that the President's apparent conviction that universal values and practical geopolitics exist in the same tension as war and peace amounts to a belief-system situated within an "amalgam of pragmatism and Niebuhrian realism". ${ }^{9}$ In practice, Obama attempted to minimize some of the harm inflicted to US foreign policy by the Bush Administration and more or less he "has handled the terrain deftly". ${ }^{10}$ That could be considered as an enormous challenge given the hostile environment of the Republican Congress and the need to manage the global recession both at home and abroad.

From 2001, the US followed a foreign policy strategy based on massive foreign commitments and interventions, which proved enormously costly in blood and treasure as well as highly unpopular around the world. This overextension was followed by a financial crisis that greatly constrained American power. The result was a foreign policy that was insolvent. Obama assumed power determined to pare down excess commitments, regain goodwill and refocus the US on core missions to achieve a more stable and a sustainable global position. He believed Iraq was an expensive mistake and drew down US forces from 142,000 in early 2009 to zero by the end of 2011. In Afghanistan, he sought to end the more costly aspects of the mission, giving priority to the fight on counterterrorism, which he embraced with ferocity in Pakistan and Yemen; and this against a doctrinal shift that allowed for a rediscovery of multilateralism and a kind of leadership aware of the rise of countries like China, India and an increasingly challenging Russian strategy under Vladimir Putin. By understanding the dynamics of globalization and interdependence and how far they are responsible for shaping the evolution of the international system - where the limitations of US power politics have been acknowledged - Obama chose the strategic significance of cooperative efforts with both allies and non-allies to combat transnational threats. Bruce Jones has illustrated this policy as an example of 'cooperative realism"11.

By the time of his reelection in November 2012, Obama's military policies and rhetoric represented a major shift. According to them, "Europe is no longer the key region shaping American grand strategy"12, nor does the Middle East rank high in the US foreign policy agenda. ${ }^{13}$ Instead, the focus has been increasingly turned on the Asia-Pacific region. This emphasis is reflected in the Defense Department's January 2012 "strategic guidance" document, which states that, "US economic and security interests are inextricably linked to developments in the arc extending from the Western Pacific and East Asia into the Indian

\footnotetext{
7 "Can the Bush doctrine last?", The Economist, March $29^{\text {th }}$-April $4^{\text {th }} 2008$.

${ }^{8}$ The White House, National Security Strategy, 27 May 2010.

9 Milne, David: "Pragmatism or what? The future of US foreign policy", International Affairs, vol.88, no.5, 2012, p. 939

${ }^{10}$ Zakaria, Fareed: "The Strategist", Time, 30 January 2012, p. 16.

${ }^{11}$ Jones, Bruce: "The Coming Clash? Europe and the US Multilateralism under Obama", in Vasconcelos, A. and Zaborowski, M. (eds.) (2009): The Obama Moment: European and American Perspectives, Paris, EU Institute for Security Studies, p.69.

${ }^{12}$ Steplak, Amir and Rachel Whitlark: "The Battle over America's Foreign Policy Doctrine", Survival, vol. 54, no.5 (October-November 2012), p.47.

${ }^{13}$ Gerger, Fawaz A.: "The Obama Approach to the Middle East: The End of America's Moment?", International Affairs, vol.89, no.2 (2013), p. 300.
} 
Ocean region and South Asia". ${ }^{14}$ White House's main priority was to pivot the US strategic gaze from Europe (and the Middle East) to China and Asia, in an effort for the US to become the central power broker in China's external relations in Asia. ${ }^{15}$

Indeed, Obama's big first-term goal was to close up the military accounts in the Muslim world so that the US could shift its attention on the Asia-Pacific region. The US troop presence in Afghanistan has been scheduled to be reduced at the end of 2014 and Obama "is seeking to keep a small number of U.S. troops in Afghanistan beyond 2014 to train Afghan security forces and conduct counterterrorism missions". ${ }^{16}$ US President willingness is to withdraw all American troops from Afghanistan by the end of 2016, but the new realities with the appearance of ISIL (Islamic State of Iraq and the Levant) as a dominant actor in the Middle East politics could fundamentally change this perspective.

In more general respects though, the US troop reduction and the less military involvement in the wider region of the Middle East freed up resources to go east. Back in 2012, Leon Panetta said the US would deploy 60 per cent of its naval assets in the AsiaPacific and 40 per cent in the Atlantic - from the previous 50:50 division. ${ }^{17}$ This deployment has been regarded as a vivid acknowledgement of the reality that Europe is no longer topping the agenda, that the US resources are finite, and an appreciation that the international environment is far from straightforward as some vocal ideologues in US (and elsewhere) would have it appear. ${ }^{18}$

The realization of US foreign policy shift was further underscored on 8 November 2012 - only a day after the reelection of Obama and in a midst of negotiations to avert a fiscal cliff - when the White House announced that the President's first overseas trip would be to Southeast Asia. ${ }^{19}$ Yet, Obama's first itinerary comprised three of China's neighbours (Cambodia, Myanmar, and Thailand), for the larger game is and will always be for some time about China. This has been the dominant perception and analysis in Washington.

If Obama is successful, US' 'rebalancing' to Asia will become his chief diplomatic legacy in 2016. However, the Middle East is not a region to ignore. War and sectarian eruptions have been reviving ancient regional quagmires. The Syrian and Iraqi imbroglios are constant reminders that the tug of war between Middle East realities and the unfolding strategy in the Pacific are already under strain through Obama's second term. ${ }^{20}$ The cases of the Middle East and the Eastern Mediterranean are not realities that Washington can afford to ignore, for they always return with a vengeance.

\footnotetext{
${ }^{14}$ Department of Defense, United States of America: "Sustaining US Global Leadership: Priorities for $21^{\text {st }}$ Century Defense", at http://www.defense.gov/news/Defense_Strategic Guidance.pdf.

${ }^{15}$ Niblett, Robert: "A Tough Second Term for Obama on Foreign Policy", 7 November 2012, at http://www.chathamhouse.org/print/187059.

${ }^{16}$ Pace, Julie: "Obama Surprises Troops in Afghanistan", 25 May 2014, at http://www.huffingtonpost.com/2014/05/25/obama-surprises-troops_n 5389274.html.

${ }^{17}$ According to the Pentagon, this will include one aircraft carrier, four standard destroyers, three Zumwalt destroyers, ten Littoral combat ships and two submarines - as well as the new base in Darwin, Australia that will host 2,500 marines. Luce, Edward: "Obama's road to Xanadu runs through Jerusalem", Financial Times, 19 November 2012.

${ }^{18}$ Milne, op.cit.,p.935

${ }^{19}$ Eddy, Melissa: "Germans feeling ignored by Obama", International Herald Tribune, 10-11 November 2012.

${ }^{20}$ Luce, Edward: "Obama's path to Xanadu runs via Jerusalem", Financial Times, 18 November 2012, at http://www.ft.com/cms/s/0/cad9e24c-2f3c-11e2-b88b-00144feabdc0.html\#axzz32tQhkQO4.
} 


\section{The Collapse of the "Ancient Regime"}

Eastern Mediterranean comprises a sensitive region of strategic dynamics gathering the interests of diverse state as well as sub-state actors and strategic realignments caused by several countries' security search, with Turkey being a case in point. The US has cast a wide political and security shadow in the region since the end of the Second World War. The cornerstone of the US strategy in Middle East has been the two major regional triangular relationships: US-Turkey-Israel and US-Egypt-Israel. ${ }^{21}$ These strategic priorities have traditionally enhanced the US interests such as maintaining a stable regional balance of power, securing the energy supply of the West and ameliorating Israel's security dilemma through boosting its ties to major littoral powers. For these reasons, the US was allowed more freedom in partly shaping and controlling the development of the regional order and providing the foundation for regional stability. ${ }^{22}$ In the case of Turkish-Israeli relations, a strategic turn was the signing of the 1996 Turkish-Israeli military cooperation agreement. ${ }^{23}$ That agreement was considered as an essential element of the US-Turkish strategic bond. It highlighted Turkey's importance in the Middle East as Israel's partner, while as a side payment it generated strong support from the powerful Jewish lobby in Washington on issues that were important to Turkey, such as countering the influence of the Armenian lobby and supporting Turkey's demands for advanced military hardware in the US Congress. ${ }^{24}$ In the case of the Egyptian-Israeli partnership, common interests included countering Iranian activism, combating terrorism and religious extremism and maintaining some form of stability by balancing out any threatening behaviors.

Since the late 2000s, however, the strategic geography that the US strived to shape has been transformed significantly ${ }^{25}$ with the advent to power of political forces that do not seem eager to support the old order foundations and policy priorities. The established relative predictability that was a fundamental characteristic two decades ago regarding supposedly customary assumptions and relationships has been completely challenged by the "Arab Spring' social turmoil and their aftermath. The two-triangles-setting has been wearing off and a new political disorder is spreading. The long-lasting Israeli-Palestinian conflict exploded in its regular spasms of violence, with the November 2012 and Summer 2014 Gaza Strip eruptions. Although, the crisis looked like a rerun of past turmoil, this time the context has been different. Traditional actors had new calculations and each tested the limits of the order in the wake of 'Arab Spring' regime changes. Netanyahu has followed an isolated approach regarding the recent Gaza war putting aside the US influence. The bloodshed started in early July 2014 provoked many US officials to express sharp criticisms against the Israeli military tactics concerning diverse attacks against Palestinian civilians putting the US-Israeli traditional alliance at risk. ${ }^{26}$ However, the US continued to provide military supplies to the

21Alterman, Jon and Malka, Haim: "Shifting Eastern Mediterranean Geometry", The Washington Quarterly, vol.35, no.3 (Summer 2012), p.111.

${ }^{22}$ Ibid, p. 114 .

${ }^{23}$ The agreement allowed, among other, the Israeli Air Force to use Turkish airspace for training, thus providing Israel with much needed strategic depth. By 2001, the US military was participating in trilateral air force and search-and-rescue exercises with Israel and Turkey.

${ }^{24}$ Aydin, Mustafa: "Reconstructing Turkish-American Relations: Divergences versus Convergences", New Perspectives on Turkey, vol. 40 (2009), p.134-135.

${ }^{25}$ Alterman and Malka, op.cit., p.111.

${ }^{26}$ The most notable attack that appalled to a great extent the US officials took place on August 3, 2014 when Israel stroke a United Nations school in Gaza. The US government talked about a "disgraceful shelling" and President Obama noticed that the deaths of innocent civilians in Gaza "have to weigh on our conscience", McGreal, Chris: "Relations are strained over Gaza but US support for Israel remains strong", The Guardian, 10 August 2014, at http://www.theguardian.com/world/2014/aug/10/united-states-israel-strained-relations-gaza. See Labott, Elise, Roth, Richard and Levs, Josh: "Has Gaza conflict brought new low in US-Israel relationship?", 
Israeli army even at the time of the Gaza conflict. Despite the tension between the two countries, as characteristically an analyst observed, "this relationship is too big to fail". ${ }^{27}$

The changing environment in the wider Middle East region has inserted in the security equation the extremist group ISIL. On August 8, 2014, President Obama announced the deployment of air forces against ISIL to protect the northern region of Iraq aiding the attempts of Iraqi Kurds to confront the militants of the newly formulated extremist group. ${ }^{28}$ Washington's return to military action in Iraq has been to a great extent justified given the strategic US interests in the region which is rich in oil resources and where a US delegation is located in Erbil. The US support to Iraqi Kurds has been planned with careful steps backing the unity of Iraq and without raising the Iraqi Kurds' hopes for their independence in the wider geographical area. Biden's proposal for a "functioning federalism" which would divide Iraq into three semi-autonomous regions for Shiites, Sunnis and Kurds could be emerged as a viable solution incorporating the political expectations of all ethnic minorities and political groups. ${ }^{29}$ However, the deep sectarian divisions rooted in the different ethnic and religious minorities located at Iraq along with the extremism that the ISIL has spread out the last two months constitute a complex conundrum. If President Obama wants to ensure the strategic interests of his country in the region, the US should be fully involved in the conflict. The capacity of the new Iraqi PM, Haider al-Abadi, to help towards the stability of Iraq is always dependent on the ability of the West to protect its interests in the wider area of the Middle East.

One positive side effect of the US military intervention in Iraq against the ISIL is the amelioration of the US-Iranian relations. Despite the fact that the two countries are old adversaries, at this moment they have to confront the same enemy, the ISIL, and provide military support to the Iraqi Government. President Obama has considered pursuing direct talks with the Iranian President Hassan Rouhani so that they will schedule a coordinated action against the ISIL forces in the northern Iraq. For the time being, we cannot see any official coordination over this front between US and Iran, but the perspective is alive. President Rouhani has declared that he will cooperate in-depth regarding the latest round of talks on Iran's nuclear programme in Vienna if the US starts direct talks with the Iranian Government. ${ }^{30}$ However, the US has not exclusively received the military support of Iran to the Iraqi Kurds as a move of good will keeping in mind that Iran attempts to exert influence on Iraqi Kurds in order to affect their own Kurds, located at Iran, from declaring independence. ${ }^{31}$

The AKP government in Turkey has been openly quite critical of the pre-existing arrangements. They have sought greater distance from Israel and adopted independent positions vis-à-vis and beyond the reach and influence of the US. The demise of earliest regional strategic regime is seen widely as having rather negative implications for the US

CNN, 5 August 2014, at http://edition.cnn.com/2014/08/05/politics/israel-us-relationship/ and Landler, Mark:

"Gaza war strains relations between US and Israel", New York Times, 4 August 2014, at

http://www.nytimes.com/2014/08/05/world/middleeast/gaza-is-straining-us-ties-to-israel.html? r=1.

${ }^{27}$ See Labott, Elise, Roth, Richard and Levs, Josh, op.cit.

${ }^{28}$ Sedghi, Ami and Arnett, George: "US military Isis air strikes in Iraq: day-by-day breakdown", The Guardian, 27 August 2014, at http://www.theguardian.com/news/datablog/2014/aug/27/us-military-isis-air-strikes-in-iraqday-by-day-breakdown.

29 "Kurdish party supports Biden's calls for a federalised Iraq", Middle East Eye, 25 August 2014, at http://www.middleeasteye.net/news/iraqs-kurdish-party-support-bidens-calls-federal-iraq-904401271.

30 "Iraq conflict: US considers talks with Iran", $B B C$, 16 June 2014, at http://www.bbc.com/news/world-middleeast-27863870.

31 Rosen, James: "Iran speeds weapons deliveries to US ally in Iraq", Foxnews, 27 August 2014, at http://www.foxnews.com/politics/2014/08/27/iran-speeds-weapons-deliveries-to-us-ally-in-iraq/. 
strategy and for Israeli security. ${ }^{32}$ The AKP elites have openly and for some time been seeking to rebalance their relations with Israel by lessening economic ties and unraveling existing security planning. Israel's neighborhood has become far more hostile. One player it could count on to contain Hamas, Egypt lies in tatters. ${ }^{33}$ In Lebanon, the Hezbollah partycum-militia holds sway. Syria is in the throes of a war that has shattered the calm on the border with Israel and whose outcome will be critical to the regional status quo. ${ }^{34}$ At the time of writing, in Iraq (and Syria), the jihadist paramilitary of ISIL continue their atrocities rendering the country ungoverned and at the verge of collapse.

In Washington each crisis has been met with trepidation without committing US resources, except for the recent deployment of US air forces in northern Iraq. Washington's response has been defined on a case-by-case basis without the traditional ideological inclinations or instinctual reactions contaminating the decision-making process. ${ }^{35}$ One thing looks clear, though: The US has a very limited capacity to affect the course of events, sort of employing significant military force. This is also the case in its help for Iraqi Kurds against the extremist group of ISIL. ${ }^{36}$ Where more action is needed, absence is offered. The US (and Europe) seems lacking the will and the power to intervene in a critically important region. Overall, American influence in the Arab world has seriously waned.

\section{In the Realm of Mutual Suspicion}

Turkey's geostrategic position was always crucial for US foreign policy objectives in the wider region of the Middle East. During the Cold War, "Turkey was a strategic imperative of the US". ${ }^{37}$ The fundamental feature that has determined the course of the relationship has been its predominantly security-oriented nature ${ }^{38}$, without a solid social and economic basis and hence without a clearly defined list of priorities: "more like a conjectural cooperation programme". ${ }^{39}$ By most accounts as already mentioned, it is Turkey's strategic location, which dictates that its importance to Washington is primarily a function of US objectives in Turkey's neighboring regions. Turkey has been seen as one of the most important forward bases through which US policies in the wider Middle East region would be implemented, and has provided the US with much needed strategic depth in its regional engagement policies. ${ }^{40}$ Given this consideration, the relationship has been rendered vulnerable and dependent on

\footnotetext{
${ }^{32}$ Since the December 2008-January 2009 war between Israel and Hamas in Gaza, Turkey excluded the Israeli Air Force from the annual Anatolian Eagle air exercise. In response to the Turkish decision, the US cancelled its participation. See Alterman and Malka, op.cit., p.119.

${ }^{33}$ In the November 2012 crisis, Hamas negotiated the cease-fire with Israel through the agency of Cairo. This may represent an important step toward Hamas becoming a more recognized player. "Hamas chief makes first visit to Gaza Strip", International Herald Tribune, 8-9 December 2012.

34" Old battles, new Middle East", The Economist, November 24, 2012.

${ }^{35}$ Milne, op.cit., p. 941-2.

${ }^{36}$ Thompson, Mark: "America is using cannons to kill mosquitoes in Iraq", Time, 28 August 2014, at http://time.com/3206804/iraq-syria-isis-obama-airstrikes/.

${ }^{37}$ Friedman, George: 'Turkey’s Strategy', Geopolitical Weekly, 17 April 2012, p.2, at http://www.stratfor.com/weekly/turkeys strategy/.

38 After almost 50 years of alliance the trade volume has remained rather low. It is noteworthy, that despite Turkey's impressive economic performance since the mid-2000s, trade with the US reached only $\$ 15$ billion in 2010 and remains overly dependent on large US defense and aircraft sales. See Council on Foreign Relations (CFR), US-Turkey Relations: A New Partnership, Independent Task Force Report No. 69 (2012), New York, p.11.

${ }^{39}$ See "Ankara and Washington: What is the problem?", Today's Zaman, 2 November 2012, at http://todayszaman.com/news/296454.

${ }^{40}$ Gerges, op.cit., p. 317.
} 
circumstantial strategic security assessments of the interests involved ${ }^{41}$, while the profound asymmetry of power is said to be responsible for Turkey's distrust of the US. ${ }^{42}$

It is not surprising that US-Turkish relations have been subject to great pressure in recent years. The end of the Cold War marked a new era for Turkish foreign policy, which has been freed from its fear of Russia, thus weakening Turkey's strategic dependence on the US. ${ }^{43}$ In the 2000s, Ankara had less existential threats to deal with, but its neighborhood was becoming (more) unstable following the 2003 military campaign against Iraq. In Washington, Turkey's geopolitical value was in doubt following the fall out over Iraq. For the US Pentagon - Ankara's most ardent advocate - Turkey's strategic importance is only valued in the context of its availability to US troops. ${ }^{44}$

At the same time, the public opinion in Turkey disregards the need for strategic support from the West and Israel, while the relationship with the US could prove "more dangerous than the threat an alliance with the United States was meant to stave off" ${ }^{45}$ In the second half of the 2000s, the EU's foot-dragging over Turkey's accession further diminished the credibility of the West. Moreover, there have been many in Turkey who began to question whether the NATO and US were still indispensable to the country's foreign and security needs. ${ }^{46}$ Turkey's growing dynamism has strengthened the perception that NATO should not be allowed to hamper the country's regional strategies as these have been embodied in Ahmet Davutoglu's 'strategic depth doctrine' ${ }^{47}$ which considers Turkey's regional relations as an asset to be used in order to advance its regional and international standing. ${ }^{48}$

AKP leaders consider the Islamic world as an equally - to the West - important component of Turkey's foreign policy. Davutoglu's foremost argument has been that Turkey has neglected its historic and cultural ties as well as its diplomatic, economic and political relations with the strategically critical Middle Eastern, North African and Eurasian regional complexes. ${ }^{49}$ In the case of the Middle East, this major policy shift has been framed in what has been described as a "neo-ottoman" platform. ${ }^{50}$ According to Han,"for the AKP, Turkey's Ottoman heritage introduced both as a sense of historical responsibility toward the Middle East and accorded it a sort of exceptionalism in the region. When a worldview propagates such exceptionalism and claim legitimacy from an ancient heritage, it becomes more likely

${ }^{41}$ Global Relations Forum (GRF): Turkey-USA Partnership at the Dawn of a New Century, Task Force Report (2011), Istanbul, p.19.

${ }^{42}$ Ibid., p.6.

${ }^{43}$ Friedman, op.cit., p. 2.

${ }^{44}$ Park, Bill: "Strategic location, political dislocation: Turkey, The United States, and Northern Iraq", Middle East Review of International Affairs, vol.7, no.2 (2003), p.9.

${ }^{45}$ Friedman, op.cit., pp. 2-3.

${ }^{46}$ Oguzlu, Tarik: "Turkey's Eroding Commitment to NATO: From Identity to Interests", The Washington Quarterly, vol.35, no.3 (Summer 2012), p.153.

${ }^{47}$ The doctrine states that Turkey should feel the responsibility to help put its region in order. This is a mission Turkey has inherited from its Ottoman past. According to Oguzlu, "the idea that Turkey needs to fulfill a particular historical mission is very much idea-politik. Though the fulfillment of this mission would likely serve Turkey's realpolitik concerns to have stability and security in surrounding regions, the motivating factor of Turkey's various initiatives in this regard is very much identity/ideology driven." See Oguzlu, op.cit., p.159-160. ${ }^{48}$ Sozen, Ahmet: "A Paradigm Shift in Turkish Foreign Policy: Transition and Challenges", Turkish Studies, vol. 11, no. 1 (March 2010), pp.103-123.

${ }^{49}$ Murinson, Alexander: "The Strategic Depth Doctrine of Turkish Foreign Policy", Middle Eastern Studies, vol. 42, no. 6 (November 2006), pp. 945-64.

${ }^{50}$ This is how, in an AKP major address, Erdogan described his party historic mission: "On the historic march of our holy nation, the AK Party signals the birth of a global power and its mission for a new world order. This is the centenary of our exit from the Middle East... whatever we lost between1911 and 1923, whatever lands we withdrew from, from 2011 to 2023 we shall once again meet our brothers in those lands". See Fradkin and Libby, op.cit. 
that the regional assessments of decision-makers will be flawed". ${ }^{51}$ Besides, it can lead to a distorted assessment of Turkey's relative power and influence. ${ }^{52}$ Under the current circumstances, Turkey's cooperation in regional contingencies should not be taken for granted in Washington and elsewhere in the West. ${ }^{53}$ Rather, more narrow definitions of interests and a quest for more autonomy of action should be expected.

It is not surprising, that according to the results of the German Marshall Fund's 2012 Transatlantic Trends Survey, favorable opinions of the US and the EU in Turkey were the lowest among the 16 respondent samples with 34 and 36 respectively. The percentage of Turkish respondents who think that Asia is more important for Turkish national interests has been 46 percent, the highest in the survey. Only 42 percent of the surveyed Turks approved of Obama's handling of international politics, the worst result with the exception of Russian respondents (26 percent); and when it comes to the handling of the negotiations with Iran concerning their nuclear program, the approval goes down to 24 percent, while 27 percent of Turks accept that Iran could acquire nuclear weapons (by far the highest score with Russians at 13 , the US at 8 and the EU12 at 6 percent); regarding fighting international terrorism only 32 percent approve Obama's policy with EU12 at 71, US 66 and Russia 38 percent. Interestingly, Turkish respondents approve Obama's handling relations with Russia less than the Russians themselves ( 36 to 38 percent). ${ }^{54}$

Turkey's evolving democratic course ${ }^{55}$ and the foreign policy strategy pursued by its current political leadership have profound implications for US interests and strategies. Turkish foreign policy has been more assertive, active and diverse, across its neighborhood. This trend is apparent regarding Turkey's approach for ISIL. Many western media and Turkey's main opposition political parties have blamed the Turkish government that it has followed an open-door policy allowing diverse groups of jihadists to cross freely the country. ${ }^{56}$ Additionally, the Turkish Government has been accused of providing weapons and training to ISIL militants as well as offering shelter to many jihadist extremists belonging to ISIL. ${ }^{57}$ These accusations have been seriously backed-up by Erdogan's declaration that "A Muslim would not do this cruelty to another Muslim brother" and his avoidance calling these militants terrorists. ${ }^{58}$ Despite Erdogan's neutral stance alongside the atrocities of ISIL militants, Turkey has followed a tricky policy regarding the conflicts in Syria and Iraq that has fallen foul of US strategic interests in the wider Middle East region. On the one hand, Turkey has joined the courageous efforts of Iraqi Kurds in fighting the extremist activities of

\footnotetext{
${ }^{51}$ Han, Ahmet K.: "Paradise Lost: A Neoclassical Realist Analysis of Turkish Foreign Policy and the Case of Turkish-Syrian Relations", in Raymond Hinnebusch and Ozlem Tur (eds.) (2013): Turkey-Syria Relations: Between Enmity and Amity, Farnham, Ashgate.

${ }^{5}$ Ibid., p. 59.

${ }^{53}$ Gerges, op.cit., p. 317.

${ }^{54}$ German Marshall Fund of the United States, "Transatlantic Trends 2012", at Www.transatlantictrends.org.

${ }^{55}$ According to a CFR report on US-Turkish relations, "Both Turkey's authoritarian legacies and the nondemocratic remedies to which the AKP has sometimes resorted during its tenure indicate that it is too early to declare Turkey a mature, liberal democracy". See CFR, op.cit., p.20.

${ }^{56}$ Solmaz, Mehmet: "Turkey continues to be target of blatant 'aiding ISIS' allegations", Daily Sabah, 27 August 2014, at

http://www.dailysabah.com/politics/2014/08/27/turkey-continues-to-be-target-of-blatant-aiding-isis-allegations.

${ }^{57}$ Solmaz, Mehmet, op.cit. and Tahiroglu, Merve: "ISIS and the threat to Turkey", The Long War Journal, 21 June 2014, at http://www.longwarjournal.org/archives/2014/06/turkeys new neighbor.php; See, also, Faiola, Anthony and Mekhennet, Souad: "In Turkey, a late crackdown on Islamist fighters", Washington Post, 12 August 2014, at http://www.washingtonpost.com/world/how-turkey-became-the-shopping-mall-for-the-islamicstate/2014/08/12/5eff70bf-a38a-4334-9aa9-ae3fc1714c4b_story.html.

58 "Erdogan's ISIS 'brothers'", Today's Zaman, 13 June 2014, at http://www.todayszaman.com/blog/mahirzeynalov/erdogans-isis-brothers 352859 .html.
} 
ISIL in the northern Iraq and, on the other hand, it provides its patronage to ISIL militants who combat the Syrian Kurds in Syria. ${ }^{59}$ In the middle of this equation, the Kurds located at Turkey's territory stand. The Turkish Government has followed a cautious stance towards Turkish Kurds diminishing their ambitions for full independence but providing them with significant rights and looking forward for the continuation of peace negotiations with PKK. ${ }^{60}$ However, US Vice President Joe Biden said on Oct. 3, 2014, that "our biggest problem is our allies". He said that Turkey, Saudi Arabia and the United Arab Emirates "were so determined to take down Assad and essentially have a proxy Sunni-[Shiite] war. ... They poured hundreds of millions of dollars and thousands of tons of weapons into anyone who would fight against Assad - except that the people who were being supplied were al-Nusra and alQaeda and the extremist elements of jihadis coming from other parts of the world." ${ }^{61}$ Biden's remarks, which provoked a sharp reaction from Turkish President Recep Tayyip Erdogan, came in the context of Biden describing the recent changes in the approach of US regional allies in dealing with terrorist groups in Syria and Iraq. There is a feeling however, thatr Turkey has begun a slow turnaround in its approach; and this is by no small degree due to increased pressure and scrutiny from the US, including the US Congress. In early October 2014, finally the Turkish parliament authorized the use of military force in Iraq and Syria. No military engagement has been reported by the time of writing but the signs of a major revision of Turkish policy are evident. Turkey has very limited choices and supporting the Syrian and Iraqi Kurds in their fighting against ISIL is probably the less risky, and the one, which makes more strategic sense. Joining the international effort against ISIL will not only strengthen Erdogan's hand at home but also restore his damaged reputation as an important regional player. Realignment with US and Western strategic interests in the region could be extremely beneficial and would definitely hold the full support of the Pentagon. ${ }^{62}$

Moreover, taking into account the current dynamism and growth trajectory of the Turkish economy none can ignore the important economic factors related to foreign policy activism. There is a growing business class in Turkey prepared to explore new markets and a government willing to place greater affinity for the region's Muslim nations, in order to meet the demands of an expanding economy. Turkey's growing demand for energy inputs has as a result increased natural-gas imports from Russia (its largest trading partner) and Iran.

Iran's growing importance for Ankara, both as a source of natural gas and a new market for Turkey's assertive export sector, should not be neglected. In the case of Iran's nuclear ambitions, the debate in Ankara seems to be mainly political rather than strategic in character. "Ankara's overt rationale has been that by acting as an intermediary between Iran and the West, rather than as a strict ally of the West, it will acquire more influence over Iran"63; however, by refusing to support the economic sanctions against Tehran and by identifying Israel as part of a nuclear Iran problem, Ankara has been breaking away from the dominant assessment of the Iranian nuclear program in the West and has been running the risk to further

\footnotetext{
${ }^{59}$ Zaman, Amberin: "Syrian Kurds continue to blame Turkey for backing ISIS militants", Al Monitor, 10 June 2014 , at

http://www.al-monitor.com/pulse/originals/2014/06/zaman-syria-kurds-rojava-ypg-muslim-pyd-pkk-turkeyisis.html.

${ }^{60}$ Cagaptay, Soner: "Turkey's Kurdish Buffer", Foreign Affairs (1 July 2014), at http://www.foreignaffairs.com/articles/141612/soner-cagaptay/turkeys-kurdish-buffer.

61 "Biden Apologizes to Turkey President in Phone Call", ABC News, 4 October, 2014, at http://abcnews.go.com/International/wireStory/turkish-president-demands-apology-biden-25961381.

${ }^{62}$ Marcus, Alize and Apostolou, Andrew: "To aid Kurdistan, look beyond Iraq", The New York Times, 18 August 2014, at http://www.nytimes.com/2014/08/19/opinion/to-aid-kurdistan-look-beyond-iraq.html? r=0.

${ }^{63}$ Reynolds, Michael: "Echoes of Empire: Turkey's Crisis of Kemalism and the Search for an Alternative Foreign Policy", The Saban Center for Middle East Policy at Brookings, Analysis Paper, no. 26 (June 2012), p. $\mathrm{v}$.
} 
polarizing its relations with Israel and the US, without actually gaining something from its engagement with Tehran. The latter's regional leadership ambitions and policies of dominating Iraq as well as strong support of the Assad regime proved to be a major obstacle, and hopes of partnership turned into bitter rivalry ${ }^{64}$. However, the new evolutions with the emergence of ISIL as a dominant actor in Middle East politics have changed the course of Turkish-Iranian relations for the time being. Both countries share a common scope in combating the radical Islamic State before it becomes a truly regional power. In addition, both countries are also "grappling with similar policy conundrums stemming from the growing assertiveness of their respective Kurdish minorities". ${ }^{65}$ In Syria, Turkey found itself on the other side of the Sunni-Shiite divide, confronted by Iran, Hezbollah and the Shiite government in Iraq, drawn, thus, in a sectarian quagmire. Turkey supports a peace resolution that Bashar al-Assad has no place and Tehran has to compromise on a common respectful political figure in order to find a solution in the unending Syrian conflict. According to many commentators and analysts, "only Turkey and Iran together can terminate the bloodshed in Syria". ${ }^{66}$ The recent visit of the newly elected Iranian president Hassan Rouhani to Turkey, in early summer 2014, bears witness to the new détente and cooperation emerging among the two countries and their officials.

In light of the above, both US and Turkey, while sharing a common view in maintaining stability in the wider region of Middle East, more than ever have obtained differing perceptions and diverging views over key policy choices and issues. Although Washington recognizes Turkey's pivotal role in the region and its value in stabilizing US relations with the Muslim world ${ }^{67}$, the relationship has become more complex and sensitive as Turkey "came to border on the US by proxy" ${ }^{\prime 68}$ adding controversy in the Turkish public debate.

The policy shift under the AKP has been so profound that many observers, both in the Western capitals and Turkey, have questioned Turkey's variation from its traditional posture. Mustafa Aydin has gone so far as to note that "the era of strategic partnership has ended"69, while Reynolds supports the view that "there is no pretense inside Ankara that its long-term interests are in fundamental alignment with those of America"70. Sayari argues that perceptions about US declining power "have been influential in Turkey's aspirations for greater independence and strategic autonomy", and Falk believes that "with the appointment of Davutoglu as Foreign Minister in 2009, Turkish foreign policy independence and activism became more pronounced". ${ }^{72}$ Erdogan seems to be more powerful after the last presidential elections in Turkey in August 2014 and what remains to be seen is the continuation of this policy with the recent appointment of Davutoglu as Turkey's Prime Minister.

\footnotetext{
${ }^{64}$ Fradkin and Libby, op.cit.

${ }^{65}$ Berman, Ilan and Madyoon, Nika: "An Iranian-Turkish reset", The Washington Times, 21 July 2014, at http://www.washingtontimes.com/news/2014/jul/21/berman-madyoon-an-iranian-turkish-reset/.

66 Yalınkılıçlı, Eşref: "Turkish-Iranian relations after Rouhani visit: Path-dependent or promising?", Daily Sabah, 28 June 2014, at http://www.dailysabah.com/opinion/2014/06/28/turkishiranian-relations-after-rouhanivisit-pathdependent-or-promising and Paul, Amanda: "Turkey and Iran: An unraveling relationship", Al Arabiya News, 12 August 2014, at http://english.alarabiya.net/views/2012/08/12/231743.html.

${ }^{67}$ Gerges, op.cit., p.316.

${ }^{68}$ Aydin, op.cit., p. 135.

${ }^{69}$ Ibid., 140.

${ }^{70}$ Reynolds, op.cit., pp. vi-vii.

${ }^{71}$ Sayari, Sabri: "New Directions in Turkey-USA Relations", Journal of Balkan and Near Eastern Studies, vol. 15, no. 2 (June 2013), p.136.

${ }^{72}$ Falk, op.cit., p. 11.
} 


\section{Breaking-up with Israel}

The June 2010 Mavi Marmara 'flotilla crisis' and the 'no' vote on Iran sanctions in the UN Security Council illustrated Ankara's intention in conducting an active but risky diplomacy across the Muslim and Arab world that has produced another independent slide in its relationship with the US. The incident had finally unearthed a significant strategic divergence on the regional security imperatives. In January 2009, the relationship reached a first low turning point as a result of Israel's decision to launch a three-week offensive military operation in the Gaza Strip. For some commentators, the clash with Israel had been in profound contradiction with the policy principle of 'zero problems' and Ankara's efforts to recalibrate the relations with the countries of the Middle East. ${ }^{73}$ For others, it has been a demonstration of vulnerability. While the AKP government was clearly keen to position itself as a champion of the Palestinian rights, they were, until the end of 2011, rather reluctant to stand up for the rights of Syrians, who were being massacred in large numbers by the Assad regime just across the border. The Turkish government was also distinctly ambivalent about the Libyan uprising. After initially opposing NATO military action against the Qaddafi regime, Ankara was forced to acknowledge that its political and diplomatic leverage with the regime was quite limited. ${ }^{74}$

In the November 2012 Gaza crisis, Prime Minister Erdogan raised his already confrontational rhetoric to another level calling Israel a "terrorist state" and challenging the US role in the Middle East. On this issue, the two governments were clearly on different frequencies. Ankara's assessment of the Gaza developments has been naturally different from that of Washington. Erdogan considers the Gaza issue as a problem that Turkey has a responsibility to get engaged by fully backing Hamas and assigning full blame on Israel. Moreover, given that Egypt is currently unable to continue as the leader of Israeli-Palestinian talks, Ankara sees a vacuum waiting to be filled. The US and Europe perceive Hamas as a terrorist organization; Turkey affixes this label to Israel. ${ }^{75}$ Erdogan and Davutoglu seem convinced that Turkey's interests lie in the popularity on Arab streets and their ability to whip up the crowds against Israel, rather than in diplomacy. A self-confident and proactive Turkey does play a major role in this conflict and no longer could identify itself as a neutral mediator. ${ }^{76}$ For Israel, this has confirmed that Ankara desires a break up of the Turkish-Israeli relations which for Erdogan is translated as a pillar for a regional leadership agenda in which alignment with Islamic currents in the Middle East is both necessary and desirable. ${ }^{77}$

Turkey's great regional and international weight means however that, diverging from the West could have serious impact on the regional balance of power and beyond. With the weakening of Egypt, old aspirations for regional primacy can become attractive again. The

\footnotetext{
${ }^{73}$ Reynolds, op.cit., p. vi.

${ }^{74}$ CFR, op.cit., p. 40.

${ }^{75}$ Foreign Minister Ahmet Davutoglu visited Gaza and expressed solidarity with Hamas. Ankara demanded that the White House officially recognize Hamas as a direct partner and give it assurance on behalf of Israel that if they halt their fire, Israel will do so as well. See Kohen, Sami:"Gaza Complicates Turkey-US Relations", Milliyet, 21 November 2012, at http://www.al-monitor.com/pulse/politics/2012/11/turkey-us-relations-gaza.html. ${ }^{76}$ Daloglu, Tulin: "Long Way to Normalcy For Turkey and Israel", Al Monitor, 10 April 2013, at www.almonitor.com/pulse/originals/2013/04/turkey-israel-apology-normalcy.

${ }^{77}$ For Eric Walberg, there are many reasons for the deterioration of the once smooth relations between Israel and Turkey: "Firstly both nations have moved away from their secular roots - Turkey with the return of Islam as a guiding principle in political life under the Justice and Development Part (AKP) in 2002, Israel with the rise of Likud in 1977 ending the long reign of Labour. Turkey is naturally returning to its traditional role under the Ottoman Caliphate as regional Muslim hegemon, while the Zionised version of Judaism has ended any pretense of the Jewish state being interested in making peace with the indigenous Muslims". See Walberg, Eric: "TurkeyIsrael Relations and the Middle East Geopolitical Chessboard. Turkey redraws Sykes-Picot", 30 September 2011, at http://www.globalresearch.ca/26867.
} 
unraveling of the pro-Western alliance in the region add up to the emergence of a regional balance of power that is rather unfavorable from Israel's perspective. ${ }^{78}$ Israel has been hardly in a position to shape the environment in which it operates. The environment shaped by the peace treaties with Egypt (and Jordan) is under great strain as new and unpredictable political forces of Islamic inclination become more powerful and legitimate in their rise. With Ankara siding with Tehran on the issue of its nuclear programme, the task of containing Iran becomes even more difficult. Altogether, the 'Arab Spring' and the deterioration of the Israeli-Turkish relations have weakened significantly Israel's external balancing strategy.

In March 2013, under the tutelage of Barack Obama, Israeli Prime Minister Netanyahu issued a formal apology to Erdogan for the flotilla raid. The move was celebrated in Ankara, but full normalization of bilateral relations is still far off. The apology, though, should be seen as a way by the US to pull Turkey back in line and on the side of the US and Israel. ${ }^{79}$ The role of Obama had been decisive. Washington tried to strengthen Israeli-Turkish relations in order to enhance Israel's security and due to the fact that Turkey was conceived as a potential facilitator in the idle Peace Process. Turkey could have played a decisive role by urging Hamas to accept the decisions of the Middle East Quartet, recognize the existence of Israel and abandon terrorism. Also, Turkey could contribute to the reconciliation between Hamas and Fatah. ${ }^{80}$ For Israel, the apology was a sort of necessity, for a country isolated in its region and with new rising security anxieties. For the Israeli PM Netanyahu, it was a cool-headed strategic decision based on the fact that in Syria the crisis and the looming threat were getting worse.

After a long period of stagnation, in December 2013, Turkey took the lead to initiate a reconciliation process in Istanbul in order to normalize the Turkish-Israeli relations. ${ }^{81}$ After difficult series of negotiations ${ }^{82}$, Israel has agreed to pay $\$ 20 \mathrm{~m}$ in compensation to the families of those killed in the flotilla raid. ${ }^{83}$ However, due to domestic imbalances and concerns in Israeli internal political scene, Netanyahu's has been hesitant to pay the bill. ${ }^{84}$ The recent outbreak in Gaza in July 2014 complicated the whole case even more. The TurkishIsrael relations have reached another low point after Erdogan's declarations about a "systematic genocide" of Palestinian people by Israel. ${ }^{85}$ Also, Turkey's support to Hamas does not help the Turkish-Israeli relations to be normalized for the time being. ${ }^{86}$

\footnotetext{
${ }^{78}$ Inbar, Efraim: "Israel's National Security Amidst Unrest in the Arab World", The Washington Quarterly, vol. 35, no. 3 (Summer 2012), p.62.

${ }^{79}$ Daloglu, Tulin: "Syrian Crisis Play a Major Role in Israeli Apology", Al Monitor, 24 March 2013, at www.almonitor.com/pulse/originals/2013/03/israel-apology-turkey-flotilla-syrian.

${ }^{80}$ Kohen, Sami:"US Seek Greater Role for Turkey in Mideast Peace Process", Al Monitor, 9 April 2013, at www.al-monitor.com/pulse/politics/2013/04/us-turkey-israel-role-mideast-peace-process.

81 Candar, Cengiz: "Time not right for Turkish-Israeli reconciliation", Al Monitor, 25 March 2014, at http://www.al-monitor.com/pulse/originals/2014/02/no-turkey-israel-reconciliation.html.

${ }^{82}$ Erkuş, Sevil: "Israel's Netanyahu delays compensation agreement with Turkey", Hurriyet Daily News, 28 April 2014 , at

http://www.hurriyetdailynews.com/israels-netanyahu-delays-compensation-agreement-withturkey.aspx? pageID=517\&nID=65641\&NewsCatID=510.

${ }^{83}$ As part of the agreement, "Turkey reportedly agreed to drop all existing claims against Israeli military who used deadly force to protect themselves against protestors who attacked them with crowbars and lead pipes as they tried to board their vessel". See Rose, Thomas: "Turkey and Israel agree to normalize relations", Breitbart, 26 March 2014, at

http://www.breitbart.com/Breitbart-London/2014/03/26/Turkey-and-Israel-Agree-to-Normalize-Relations.

${ }^{84}$ Erkuş, op.cit.

85 Arbell, Dan: "Despite Gaza conflict, Turkey and Israel would benefit from rapprochement", Brookings, 22 July 2014, at http://www.brookings.edu/blogs/iran-at-saban/posts/2014/07/22-arbell-turkey-israel-look-beyondgaza-restore-ties. See, also, Culzac, Natasha: "Israel-Gaza conflict: Turkish PM says Israel 'will drown in the blood it has shed' in heated condemnation", The Independent, 4 August 2014, at
} 
The current situation in the Middle East is much more radical, much more Islamic, much more religious and much more hating of Israel. The dominant perception in the US and Israel supports the view that Ankara's stance clearly undermines the already slim prospects for any meaningful solution and, in the name of Islamic solidarity, Ankara puts the wider security issues of the region at risk. Nobody should expect Turkey-Israeli relations to return to the pre-2009 days. An important feature of the AKP political culture is to oppose Israel with "anti-Israelism" increasingly an eminent feature. It is doubtful whether this will change in the near future. Mutual suspicion and lack of confidence between the two will continue for a long time, no matter what is done. ${ }^{87}$ Returning to the high days of strategic diplomatic and military cooperation is not very likely. There are those who believe that severing ties with Israel has been a pre-meditated decision in Erdogan's course to "become the Sunni leader of the Middle East" ${ }^{88}$ A deep and lasting normalization will certainly require a strategic and geopolitical reassessment by all involved in the major regional questions (like Israeli security, Palestinian statehood, Muslim alignments along the Sunni-Shiite axis etc.). The map of the Middle East is coming apart and the US is regrouping in the face of events in Syria.

\section{The Sectarian Trap in Syria}

Many commentators have described Turkey's involvement in the Syrian civil inferno as the par excellence failure of Davutoglu's 'doctrine'; an ill-defined strategy, which has backfired as the conflict has descended into sectarian warfare. ${ }^{89}$ Assad turned to Erdogan's archenemy after the Turkish leader greatly misjudged ancient regional realities and overestimated Turkey's capacity to influence the unfolding developments. ${ }^{90}$ An ambition to elevate Turkey to the status of regional game setter revealed an underestimation of the complex regional demographic, religious and political make-up with deep sectarian fault-lines. ${ }^{91}$ Ankara clearly underestimated the resilience of the pro-Assad forces and over-estimated the willingness of the US and Europe to take the risk to forcing the Assad regime from power. ${ }^{92}$ On October 4, 2012, the Turkish military pounded targets inside Syria in retaliation for a mortar attack a day earlier that killed five civilians in Turkey. Turkey's Parliament approved a motion the same day that authorized further military action against Syria and permitting cross-border raids.

http://www.independent.co.uk/news/world/middle-east/israelgaza-conflict-french-minister-says-solution-mustbe-imposed-as-turkeys-pm-accuses-israel-of-deliberately-killing-mothers-and-children-9646491.html and

"Turkey warns Israel against 'consequences of its aggression'", Today's Zaman, 18 July 2014, at http://www.todayszaman.com/diplomacy turkey-warns-israel-against-consequences-of-itsaggression 353399.html.

${ }^{86}$ Gidda, Mirren: "Hamas still has some friends left", Time, 25 July 2014, at http://time.com/3033681/hamasgaza-palestine-israel-egypt/.

${ }^{87}$ Gursel, Kadri: "Turkey Seeks Ottoman Sphere of Influence", Al Monitor, 3 April 2013, at

www.al-monitor.com/pulse/originals/2013/04/turkey-normalization-israel.

${ }^{88}$ Caspit, Ben: "Israeli-Turkish Reconciliation Not a Done Deal", Al Monitor, 23 April 2013, at www.al-monitor.com/pulse/originals/2013/04/talking-reconciliation-in-ankara.

${ }^{89}$ Since the mid-2000s the AKP government invested in Assad and in good relations with Syria. Ankara was instrumental in bringing the Syrian regime out of international isolation after the Hariri assassination in Lebanon and played a major role in 2007 and 2008 with its mediation efforts between Syria and Israel over the Golan Heights. In April 2009, the two states conducted their first ever, joint military exercise to be followed in September by the establishment of a 'Senior Strategic Cooperation Council'. With the uprising in Syria in March 2011, Ankara tried to counsel Assad to implement social, economic and political reforms only to discover the limits of its influence. By November 2011, Erdogan called for Assad to step down and openly supported the Syrian opposition.

${ }^{90}$ Idiz, Semih: "Turkey Miscalculates Syria", Al Monitor, 19 March 2013, at www.al-monitor.com/pulse/originals/2013/03/turkey-davutorlu-syria-policy-failure.

${ }^{91}$ Ibid.

${ }^{92}$ Stephens, Philip: "Turkey has stumbled on the road to Damascus", Financial Times, Friday, 26 October 2012. 
Earlier, in June 2012, Syrian forces had shot down a Turkish warplane with Ankara refraining from responding. ${ }^{93}$

Fears of escalation have always been present but the reality is that the international community demonstrated no appetite for creating, for example, safe havens along the SyriaTurkey border or the sort of no-fly zones imposed in Iraq in the 1990s, let alone engaging militarily in a violent sectarian conflict such as the one in Syria. ${ }^{94}$ Russia (and China) predictably vetoed a UN Security Council statement condemning the Assad regime. US and Europe lack the willingness (and the capability) to weather the geopolitical storms in the Middle East and Turkey - or anyone else for that matter - can hope to assume this role. And there are no good options in Syria. The fighting has unearthed the deep divisions between Sunni, Alawite, Kurd and other smaller minority groups. The anger and hatred will be long lasting. The war has affected and gravely destabilized the fragile status quo Iraq and threatens Lebanon. Worse, it has accentuated the Sunni-Shiite antagonisms within Islam and it has fueled the confrontations between extremists and mainstream Islam across the Arab world. ${ }^{95}$ The emergence of ISIL as a violent regional actor unfortunately adds credibility to this analysis.

Ankara, involved in the conflict to a great extent, has felt as if it has been left alone and is frustrated by the lack of international support towards more concrete and practical action. Any help would be focused on Turkish self-defence, rather than addressing the broader Syrian crisis. ${ }^{96}$ Turkey's involvement was seen as increasingly sectarian, its relations with regional actors were strained and its potential for regional leadership undermined. ${ }^{97}$ However, the handwringing may not be politically sustainable if the Syrian crisis were to inexorably expand into Iraq, Lebanon and the Israeli-occupied Golan Heights. The whole situation in the Middle East has been transformed to a complex puzzle after the appearance of ISIL and the limitless violence employed by this extremist group. Pressure for more direct, multilateral intervention could be harder to bear.

In 2013, before the emergence of ISIL and in contrast to Ankara perspectives, Washington, as one of the major international players, had formed a different blueprint for the region. The two countries, Turkey and US, agreed that the Assad regime should be kicked out and the crisis ought to be terminated in the short-term otherwise it would provoke a lostlasting bloodshed without clear visions for the future of the region. However, the perception of the US was totally different compared to the Turkey's aspirations. As a study of National Security Program clearly put it: "Like in Iraq, however, the United States sees a pluralistic government as the only means of preserving the unity of the state and preventing a return to violence by creating government as a venue where the voices of all ethnic and religious groups can be heard". 98 The US approach had a strong political component whereas Turkey was looking clearly for a military solution to the conflict. Only if Turkey would be ready to

\footnotetext{
93 "Turkey's Parliament Approves Further Military Action Against Syria", The New York Times, October 4, 2012, at http://www.nytimes.com/2012/10/05/world/middleeast/syria.html.

${ }^{94}$ The only clear 'red line' laid down by the US is the use of chemical weapons. Syria has made clear it will not use them unless attacked by an outside power. "No one, including Turkey, wants the Syrian conflict to spread", The Guardian, 4 October 2012.

${ }^{95}$ Cordesman, Anthony H.: Syria: The Search for the Least Bad Option, CSIS Burke Chair in Strategy, 3 April 2013.

96 "Syria and Turkey: how long can the world's great powers sit on their hands?", The Guardian, 4 October 2012.

${ }^{97}$ Grigoriadis, Ioannis: "The "Davutoglu Doctrine" under pressure: Challenges for Turkish Foreign Policy in a Changing Middle East", ELIAMEP Thesis 3/2012, October 2012, p. 1.

${ }^{98}$ National Security Program: From Rhetoric to Reality: Reframing U.S. Turkey Policy, Foreign Policy Project, October 2013, Ambassadors Morton I. Abramowitz and Eric S. Edelman, Bipartisan Policy Center.
} 
abandon the military bandwagon, the US could trust it as an equally partner regarding the peaceful settlement of the dispute.

Turkey has a big stake in the outcome of the conflict for there are two additional problems. There is a big influx of refugees, and, most importantly, there is the Kurdish dimension of the crisis. Regarding the refugee problem, from the inauguration of the Syrian crisis, in March 2011, there were signs that the refugee waves towards Turkey would be increased with varied implications for the economy of Turkey and the future of the Syrian conflict. Except for its role as a facilitator to the Syrian crisis between the two opposing camps, Turkey had to play a second crucial role as a humanitarian aid provider and refugee host. ${ }^{99}$ The region of Hatay, especially, has received an enormous wave of refugees rendering the wider territory as a source of insecurity. The Turkish government has attempted to weaken the implications of the refugee problem through the creation of refugee camps across the borders of Turkey. However, the incidents of tension between the local population and the refugees are growing and it is more than obvious that the humanitarian problem has been aggravated constituting a fireplace of violence and danger.

The Syria crisis has to a significant degree brought to the fore the 'Kurdish issue' and showed that it has dimensions beyond being an internal problem of Turkey. More than twenty years ago, during the first Gulf War, the notion of a divided Iraq became in fact one of Turkey's traditional nightmares. The fear was that Iraq's division would result in an independent Kurdistan, which would fuel Kurdish separatism in Turkey. That fear appears to have receded with the economic and political ties that have developed between KRG in Erbil and Ankara. The threat seemed to stem less from the Iraqi Kurds and more from the now ousted Prime Minister Nouri al-Maliki and his overtly sectarian policies, which favored Iraq's majority Shiites against the minority Sunnis. ${ }^{100}$ Due to this fact, Ankara provided unconditional support and refuge to Iraq's Sunni Deputy President Tariq al Hashimi, who faces a death sentence in Baghdad for allegedly setting murderous squads on Shiites in the past. Erdogan's strong criticisms of Maliki and Ankara's open support of Iraqi Sunnis reflected Turkey's sectarian sympathies, a fact that is also seen in Ankara's approach to the Syrian civil war. Furthermore, Turkey's increasing cooperation with Iraqi Kurds in the strategic energy sector, developed over Baghdad's head, had also fueled Maliki's anger towards Turkey. Given Turkey's deepening relations with the KRG, its continued support for Iraqi Sunnis and differences over Syria, tensions between Ankara and Baghdad will probably continue to fester for some time. The new Iraqi PM, Haider al-Abadi, and the dominance of ISIL in major Iraqi cities may change this perspective in favour of a close cooperation between Turkey and Iraq.

In this geopolitical juncture, Erdogan realized that Turkey needs to move forward and he engaged in direct talks with Ocalan and PKK European representatives. That decision was not easy but it was to a large degree the result of intense geopolitical pressures and compelling regional circumstances. Deepening trade, energy and diplomatic relations with KRG, emphasizing hostility with Baghdad, exerting influence on Syria's autonomy and seeking Kurds can be characterized as critical determinants of Turkey's foreign policy. Also,

\footnotetext{
${ }^{99}$ Ilgit, Asli and Davis, Rochelle: "The many roles of Turkey in the Syrian crisis", Middle East Research and Information Project, 28 January 2013, at http://www.merip.org/mero/mero012813.

${ }^{100}$ One of the principle results of the 2003 U.S. invasion of Iraq was that it released the Shiite genie out of the Middle East bottle. Clearly, in retrospect, the implication of Iraq's demographic makeup — in which the Shiites constitute the overwhelming majority — was not considered sufficiently by the Bush administration at the time. The result, with foreign Sunni Jihadist groups pitching in to turn the country into a sectarian bloodbath, is an increasingly polarized Iraq, which has come to the brink of division along ethnic and sectarian lines. The U.S. invasion of Iraq also worked to predominantly Shiite Iran's advantage, providing Tehran the opportunity to expand its regional influence by playing the sectarian card.
} 
Turkey's open hostility against the Syrian regime resulted in a convergence between the PKK's military wing based at Iraqi Kurdistan's Kandil Mountains and the Tehran-Damascus axis. The PKK put itself squarely into the equation of the Iran-Syria axis with the support of Russia following 2011. Just as Iran and Syria have become an "acecard" for the PKK, the PKK has become more valuable for Iran and Syria than ever before. In Syria, the PKK and the PYD have placed themselves between the regime and the opposition, if somewhat nearer to the regime. They have entered a period when they are more reluctant to disarm, becoming regional players, far beyond a mere security nuisance for Turkey.

The prospect of having to deal with an increasingly assertive Kurdish statehood-seeking population in its borders left Ankara with one viable strategic option: to work with them. It became a strategic imperative to neutralize the PKK by disengaging it from the TehranDamascus alliance. Turkey had no real leverage to dissuade the PKK leaders at their Kandil Mountains headquarters adjacent to Iran. Only Ocalan could exercise real influence. ${ }^{101}$ On 21 March 2013, a cease-fire came into effect. The perspectives were optimistic for a brave breakthrough. However, the peace process was devastated soon after its beginning. Erdogan's approach to start negotiations with Massoud Barzani, the president of the KRG in northern Iraq, probably means that reviving the process will be exteremely unlikely in the near future. $^{102}$

However, the appearance of ISIL as an autonomous and self-governing regional actor in the region and its active military intervention has changed the political and security dynamics to a great extent. Obama has already started to think for a soft military intervention via airstrikes in Syria with the support of its major international allies, the EU, Great Britain, Australia, in order to regain access to key military bases and confront in depth the challenge of ISIL brutalities. ${ }^{103}$ For this scope, currently, the US supports overtly the Syrian rebel groups fighting against both the Assad regime and the ISIL extremists. ${ }^{104}$ The US and its allies should also provide military support to countries like Lebanon, Jordan, Saudi Arabia, Qatar and United Arab Emirates and obtain their dedicated help and support against the expansion of ISIL in the region. In this respect, Turkey has to join these forces and revise completely its policy regarding the Syrian conflict by abandoning its backing to the ISIL extremist groups and cooperating with the Syrian Kurds. It has been reported that much of Syria's Kurds hope to use the civil war as an opportunity to carve out an autonomous or even sovereign Kurdish region in Syria. For Ankara, this is simply unacceptable, due to the fact that such a development could embolden Kurdish separatists elsewhere. ${ }^{105}$ In 2012 , the PKK launched its most intense campaign against Turkish armed forces. The main perception across in Ankara has been that Syria's Kurds have been assisting the PKK. ${ }^{106}$ Emergence of Syrian

\footnotetext{
${ }^{101}$ Candar, Cengiz: "Turkey's Kurdish Initiative in Regional Context", Al Monitor, 7 April 2013, at www.almonitor.com/pulse/originals/2013/04/syria-iraq-aspects-turkey.

${ }^{102}$ Gunter, Michael N.: "TheTurkish-KurdishPeaceProcessStalled in Neutral", Turkish Inside, vol. 16, no. 1 (Winter 2014), pp.19-26.

103 "US reportedly recruiting allies to support expanded airstrikes, Syrian opposition", Foxnews, 27 August 2014, at

http://www.foxnews.com/politics/2014/08/27/us-reportedly-recruiting-allies-to-support-expanded-airstrikessyrian/.

$\frac{}{104}$ Hosenball, Mark: "Exclusive: Obama authorizes secret U.S. support for Syrian rebels", Reuters, 1 August 2014, at http://www.reuters.com/article/2012/08/01/us-usa-syria-obama-order-idUSBRE8701OK20120801.

${ }^{105}$ Turkey has warned Masoud Barzani, president of the Iraqi Kurdistan Regional Administration, that the autonomous region in northern Iraq would not be applied to Syria and Turkey's stance would be very different than it was in Iraq. See "Ankara warns Barzani over autonomy in Syria", Hurriyet Daily News, November 3-4, 2012.

${ }^{106}$ Paul, Amanda: "Turkey gets tough on Syria", Sunday’s Zaman, 7 October 2012.
} 
Kurds under the leadership of the Democratic Union Party (PYD) - seen as Syrian offshoot of the PKK - affixed regional context to Turkey's Kurdish issue. PYD has taken over control of many Kurdish settlements along the 911 kilometers Turkish-Syrian border. At this time, though, the Syrian Kurds along with the Free Syrian Army comprise the basic fighters against the expansion of ISIL in Syria. ${ }^{107}$ If Turkey wants to play a major role towards the end of the Syrian crisis, it should change its policy pursuing a viable cooperation with the rebel groups that combating both the Assad regime and the ISIL paramilitaries. This perspective would also be the basis for an overall solution to the Kurdish problem. But this stake is not an easy task. Everything will depend on the resistance of ISIL to continue dominating in the wider geographical space of the Middle East and the willingness of Turkey to compromise in a workable solution regarding the Kurdish issue.

The Syrian crisis will continue to be the source of major problems for Ankara, given Ankara's serious miscalculations. First, there was a wrong prediction on how long Assad would last and what he is capable of doing. Second, Turkey also miscalculated Assad's isolation. Ankara truly believed that Assad's supporters would only provide moral support and the West, under the leadership of the US and Turkey, would easily topple the regime. Yet, Iran turned out to be extremely generous when it came to provide military and economic support to Assad. Ankara underestimated Moscow's political support to Assad and the importance it attached to the survival of the regime. Finally, Turkey's unrestrained confidence in the Syrian National Council, Free Syrian Army and other armed groups fighting Assad became a serious nuisance for Ankara. Turkish diplomacy relentlessly defended Jabhat alNusra against the concerns and criticism of the West. Despite the risks of letting them loose, these groups were granted special border passage privileges. ${ }^{108}$ They were finally designated terrorist on June 3, 2014, following an official Turkish claim that the May 2013 Reyhanli bombing which killed 52 and wounded more than a hundred was actually an al-Qaeda attack and not a Syrian regime one. ${ }^{109}$ The decision was seen as further proof of Turkey's failed Syria policy, which has left the Erdogan government little choice but to fall in line with the US with regard to radical groups fighting in that country. Although Turkey does not admit that its Syria policy and its vision of having zero problems with neighbors failed, there is no end in sight to the radicalization of the Syrian theater. It's like a free-for-all jihadist camp and it has already contaminated Iraq. While the US and Europe were equally dismal in their strategic and tactical approach to the Syrian war, Turkey's failure is even more profound due to its geography and Erdogan's public statements that made the toppling of Assad a state policy. Whether or not Assad will leave the Syrian political scene, it is a very difficult question to be answered. Erdogan and Davutoglu also do not have a clear response to this. Moreover, since Assad's departure doesn't straightforward mean stability, the security anxieties for Turkey are likely to persist during the transition period. While Turkey's political leaders do accept only the overall Assad's overthrown from the power, the Erdogan government will possibly accept diverse elements of the regime that have to be incorporated into a transitional government ${ }^{110}$ so that it secures that country's unity.

\footnotetext{
107 "Syrian Kurds, rebels find common enemy in ISIS", Al Monitor, 7 June 2013, at http://www.al-monitor.com/pulse/originals/2014/03/syria-kurds-pyd-ypg-isis-rebels-kobani-afrin.html. ${ }^{108}$ Zeyrek, Deniz: "Turkey's Syria Policy: Success or Bankruptcy?", Radikal, 26 May 2013.

109 "Turkey finally designates Jabhat al-Nusra a terrorist group", Al Monitor, 6 June 2014, at http://www.almonitor.com/pulse/originals/2014/06/turkey-al-nusra-terrorist-organization-syria-al-qaeda.html?utm

${ }^{110}$ Erdogan's visit to Washington in May 2013, marked a so-called "synchronization" of Syrian policy between the US and Turkey. Representatives of the Assad government and the opposition have already met at a conference in Geneva (the so-called Geneva II). The goal was to agree on a cease-fire and a transitional government. If the Assad side flees the table in this process, then Russia will be pressed to support sanctions at the Security Council. While the Geneva process continues, direct humanitarian assistance to Syrian refugees will
} 
Turkey's role in the wider strategic environment is affected by protracted chaos, sectarian violence and a resulting black security hole across the border. ${ }^{111}$ Not so long ago, Turkey was welcoming the US retreat from the regional scene. With the Syrian conflict, it is angered by the US and NATO refusal or inability to intervene, ${ }^{112}$ or to even aid Turkey. ${ }^{113}$ Fears of escalation are quite strong and Washington does not want to be trapped into another Iraq-type engagement. ${ }^{114}$ The strategy outlined by President Obama on 11 September 2014 with escalating US military involvement against the of ISIL in the form of more air strikes is a testament that the political dynamics in Washington may be changing but not as a result of the Assad regime atrocities. It has been the prospect of a jihadist regime consolidating itself that has been treated as a threat to the national security of the US, which has forced Washington to act.

However, the fact remains: No predictions can be made as far as Syria is concerned. ${ }^{115}$ As Cordesman noted, "every current element of the present conflict is having a steadily more crippling effect and is more polarizing both within Syria and the region around it". ${ }^{116}$ Second, the crisis has been a manifestation of the fact that Turkey "has neither the power not the strength to sustain a care role in Eastern Mediterranean". Rather, it remains "a plausible yet volatile actor on the edge of the subsystems of continental Europe and the Middle East". ${ }^{117}$

\section{Conclusion}

Despite all the joy that came with the 'Arab Spring' popular uprisings in 2011, the Arab Middle East remains a very unstable and unpredictable region where the multidimensional crisis cannot be expected to produce viable, functional and more democratic regimes anytime soon. Rather, weak states will continue to struggle both domestically and in the foreign policy conduct. ${ }^{118}$ Following the US withdrawal from Iraq and its re-entering in August 2014, the partial vacuum left the door open and allowed more room for regional players to assert themselves. Such a prospect means that Washington might need to reassess its overall Eastern Mediterranean and Middle Eastern strategy. A region embroiled in Syrian-type conflict is not the foundation for regional power and security projection it once was. Strained relations with Turkey will complicate US strategic calculations and stability seeking. ${ }^{119}$

\footnotetext{
be increased. Covert weapons and ammunition support to the Syrian opposition will continue and necessary measures will be taken to prevent the further strengthening of internationally linked terror groups like Jabhat alNusra.Zeyrek, 'Turkey's Syria Policy'.

${ }^{111}$ Lesser, Ian O.: "Turkey, Syria and the Western Strategic Imperative", Global Turkey in Europe, Commentary 02 (July 2012).

${ }^{112}$ The best the US has offered is logistical and intelligence support for the rebels and humanitarian aid for the refugees. Washington has indicated that it would not supply sophisticated weapons fearing that these would fall into the hands of the Islamic militants who have flocked to the cause of the rebels.

${ }^{113}$ Turkey lacks important defence systems for deployment against other regional actors, such as Syria. The US has been very reluctant to export the necessary equipment, such as Super Cobras, not to mention high-tech unmanned weapons like Predators. See "Ankara and Washington: What is the problem?", Today's Zaman, 2 November 2012, http://todayszaman.com/news/296454.

${ }^{114}$ Gerger, op.cit., p. 310.

${ }^{115}$ For an interesting discussion on Syria in late 2011, see Chatham House: "Scenarios for Syria", MENA Programme: Meeting Summary, 2011, at www.chathamhouse.org/mena.

${ }^{116}$ Cordesman, op.cit.

${ }^{117}$ Robins, Philip: "Turkey's "double gravity" predicament: The foreign policy of a newly activist power", International Affairs, Vol.89, No.2 (2013), pp.382.

${ }^{118}$ Inbar, op.cit.

${ }^{119}$ Alterman and Malka, op.cit., pp. 122-123.
} 
These realities certainly redefine Turkish-US relations as they have recast Turkey's regional role and its relations with Syria and Iran. Significant differences in perceptions and policies emerged since the late 2000s that have still not been cast away and will most probably not for some time. The AKP's foreign policy agenda seems to reflect a rather sectarian approach, with emphasis on Muslim solidarity, engagement with the Middle East and embrace of actors hostile to the US, the West and Israel. This policy has been popular in the domestic arena as well as consistent with a commonsense approach that sees Turkey the leader of Sunni Islam and the Muslim Brotherhood movements. It has been a policy, though, that run into the political and social realities of the region. Syria turned out to be the crisis on which Turkey's Middle East engagement policy foundered in ways unexpected by the AKP leadership. Success has not been forthcoming and a process of redefinition may be underway. The gap between grand designs and the regional realities of "ferocious rivalries and inflexible dogma" is nothing but narrowing, while there are others (like Egypt) who will again try to lay claim to the leadership of an Arab world increasingly de-secularizing. ${ }^{120}$

What this article has tried to examine is that US interests in Turkey are engaged in important ways: The US has a stake in the evolution of Turkey as an actor whose condition influences - to a point - the future of regions that Washington cares about and although Turkish-US relations had suffered serious setbacks, the US cannot afford to let the situation deteriorate further, as long as Turkey "remains a western-oriented stable country in a very problematic neighborhood". ${ }^{121}$ Although the potential for regional security cooperation remains substantial, with Turkey emerging as a more independent regional player - at times even at cross-purposes with the US - strategic convergence, though, requires new thinking. On issues of current strategic priority - Iraq, Iran, Syria, Egypt, the Middle East peace process and potentially Russia - differences in perception and approach are not easy to dismiss, and interpretations of security concerns do not always coincide. Although US matters to most major security policy issues that confronts Turkey today and in the years ahead, Turkey matters to the US primarily as part of a wider regional security system. As the Americans set global imperatives with regional applications, of utmost importance will be the balance between Turkey and the US regarding strategic objectives and tactical commands for the future of the region. Agreement in the first one (strategic objectives) by no means implies compatibility in the second (tactical commands). In this respect, even in areas where both have an interest, Turkey might not be the most likely agent of change, at least for now.

\footnotetext{
${ }^{120}$ Gerges, op.cit.

121 Aydin, op.cit., p. 141.
} 